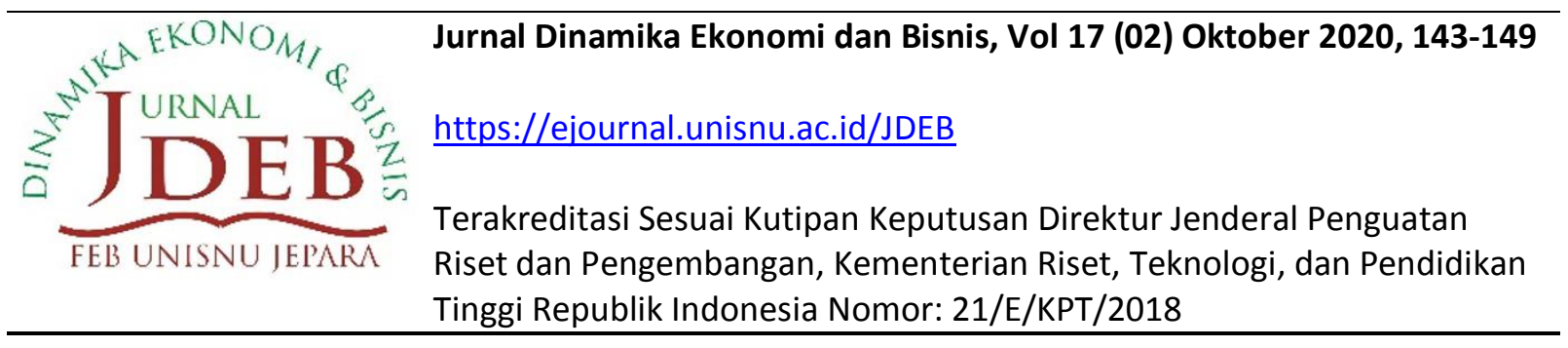

\title{
Pengaruh Struktur Modal, Ukuran Perusahaan dan Pendidikan Dewan Komisaris Terhadap Kinerja Perusahaan Manufaktur di Bursa Efek Indonesia
}

\author{
Emi Sumartini \\ Fakultas Ekonomi dan Bisnis, Universitas Pembangunan Nasional Veteran Jakarta \\ Email: emisumartini1@gmail.com
}

\begin{abstract}
This research is using quantitative study aimed to see whether there are influence of capital structure, firm size, and background education of board of commissioner on firm performance. The regression method were applied on annual financial report of manufacturing sector from 2016-2018. The finding shows that capital structure, measured by debt to equity ratio and background education of board of commissioner have no significant effect on firm performance. Firm size measured by total sales was positive significant on firm performance.
\end{abstract}

Keywords: Background Education of Board of Commissioner, Capital Structure, Firm Performance, Firm Size

\begin{abstract}
Abstrak
Keberhasilan pemilik perusahaan dalam mengelola perusahaannya dapat diukur dari kinerja perusahaan. Perusahaan yang baik sudah pasti memiliki kinerja yang baik. Kinerja keuangan perusahaan yang baik akan berpengaruh pada kinerja perusahaan. Penelitian ini bertujuan untuk mengetahui pengaruh struktur modal, ukuran perusahaan, dan latar belakang pendidikan dewan komisaris terhadap kinerja perusahaan. Penelitian ini merupakan penelitian kuantitatif. Jenis data yang digunakan adalah data sekunder yang diperoleh dari laporan tahunan perusahaan manufaktur sektor indusri barang konsumsi yang terdaftar di Bursa Efek Indonesia pada tahun 2016-2018. Metode regresi diterapkan pada laporan tahunan perusahaan sektor manufaktur selama tahun 2016-2018. Hasil penelitian menunjukkan struktur modal yang diukur dengan debt to equity ratio dan latar belakang pendidikan dewan komisaris tidak memiliki pengaruh terhadap kinerja perusahaan. Ukuran perusahaan yang diukur dengan total penjualan memiliki pengaruh signifikan positif terhadap kinerja perusahaan.
\end{abstract}

Kata Kunci: Kinerja Perusahaan, Latar Belakang Pendidikan Dewan Komisaris, Struktur Modal, Ukuran Perusahaan

Sitasi: Susanti, E. (2020). Pengaruh Struktur Modal, Ukuran Perusahaan dan Pendidikan Dewan Komisaris Terhadap Kinerja Perusahaan Manufaktur di Bursa Efek Indonesia. Jurnal Dinamika Ekonomi dan Bisnis, 17 (02) 2020, 143-149. 


\section{PENDAHULUAN}

Keberhasilan pemilik perusahaan dalam mengelola perusahaannya dapat diukur atau dilihat dari kinerja perusahaan itu sendiri. Perusahaan yang baik sudah pasti tentunya memiliki kinerja yang baik. Kinerja perusahaan sendiri dapat diukur dengan beberapa pengukuran, seperti misalnya Return to Asset (ROA) dan Tobin's Q. Pengukuran kinerja perusahaan pada penelitian kali ini menggunakan Tobin's Q. Smithers dan Wright (2008) menjelaskan bahwa Tobin's $Q$ memiliki keunggulan seperti dapat menggambarkan aset perusahaan secara keseluruhan, menunjukkan sentimen pasar (misalnya analisis yang dilihat dari prospek perusahaan atau spekulasi), dan mencerminkan modal intelektual perusahaan (Widiastri dan Yasa, 2018). Indikator kinerja perusahaan salah satunya adalah kinerja keuangan. Kinerja keuangan perusahaan yang baik akan berpengaruh pada kinerja perusahaan yang baik pula. Pada penelitian ini kinerja keuangan yang akan diukur pengaruhnya terhadap kinerja perusahaan adalah struktur modal dan ukuran perusahaan. Selain indikator kinerja keuangan, adanya good corporate governance adalah salah satu indikator terwujudnya kinerja perusahaan yang baik juga. Salah satu aspek bahwa perusahaan memiliki tata kelola yang baik adalah adanya dewan komisaris yang bekerja sesuai dengan tugasnya. Tugas dari dewan komisaris ini adalah mengawasi bahwa perusahaan telah berjalan sesuai dengan visi dan misinya serta tidak mengabaikan kepentingan pemegang sahan (stockholder) dan pemangku kepentingan (stakeholder). Dewan komisaris dapat bekerja sesuai dengan tugas dan tanggung jawab masing-masing dengan baik dipengaruhi oleh latar belakang pendidikan dewan komisaris tersebut itu sendiri.

Menurut Jensen dan Meckling (1976), teori agensi adalah teori yang menggambarkan hubungan antara pemberi kontrak (prinsipal) dan pelaksana kontrak (agen). Keagenan muncul ketika prinsipal meminta agen melakukan pekerjaan dan mendelegasikan wewenang pembuatan keputusan kepada agen. Agen bertindak atas nama prinsipal untuk memaksimalkan kesejahteraan prinsipal dan memiliki kewajiban untuk mempertanggungjawabkan apa yang sudah terlebih dahulu diamanahkan oleh prinsipal. Pemisahan fungsi antara prinsipal dan agen dapat menimbulkan masalah karena perbedaan kepentingan antara prinsipal dan agen (Jensen dan Meckling, 1976). Menurut Scott (1997), inti teori keagenan adalah perancangan kontrak yang tepat untuk menyelaraskan kepentingan prinsipal dan agen dalam hal adanya konflik kepentingan. Kontrak yang optimal adalah kontrak yang meminimalkan biaya keagenan (Wijayati, 2015). Tata kelola perusahaan dan kinerja keuangan merupakan faktor yang penting dalam memaksimalkan kekayaan para pemegang saham (Ahmed et. al, 2019). Tata kelola perusahaan yang baik merupakan indikasi bahwa investor akan mendapatkan pengembalian modal yang optimal dari investasi mereka dan kinerja keuangan yang baik meminimalisir risiko kemungkinan kebangkrutan dari sebuah perusahaan. Tata kelola perusahaan dan kinerja keuangan yang baik dapat terwujud apabila kepentingan prinsipal dan agen selaras atau tidak terjadi konflik kepentingan apapun.

\section{METODE}

Metode kuantitatif adalah metode yang digunakan dalam penelitian ini. Jenis data yang digunakan adalah data sekunder yang diperoleh dari website Bursa Efek Indonesia yaitu www.idx.co.id dan website resmi masing-masing perusahaan. Data yang digunakan dalam 
penelitian ini adalah data dari laporan tahunan perusahaan manufaktur sektor indusri barang konsumsi yang terdaftar di Bursa Efek Indonesia pada tahun 2016-2018. Teknik analisis data yang digunakan dalam penelitian ini adalah analisis regresi linier berganda. Pada penelitian ini struktur modal diukur menggunakan Debt to Equity Ratio (DER), Ukuran Perusahaan diukur menggunakan logaritma natural dari Total Penjualan, Latar Belakang Pendidikan Dewan Komisaris diukur dengan membagi jumlah dewan komisaris berlatar pendidikan manajemen dengan seluruh jumlah dewan komisaris, sedangkan kinerja perusahaan diukur menggunakan rumus Tobin's Q.

\section{HASIL}

Penelitian ini dilakukan pengujian pada 39 sampel yang didapat setelah dilakukan outlier. Pada 39 sampel tersebut dilakukan uji statistic t untuk mengetahui apakah suatu variabel independen yang dikendalikan oleh variabel pengendali secara parsial memiliki pengaruh yang signifikan atau tidak terhadap variabel dependen. Sedangkan nilai t tabel pada penelitian ini adalah 2,0301.

\section{Tabel 1. Hasil Uji-t Model}

\begin{tabular}{llc}
\hline Coefficient & t-hitung & sig \\
\hline (Constant) & $-1,249$ &, 220 \\
Struktur Modal & $-1,951$ &, 059 \\
Ukuran Perusahaan & 2,105 &, 043 \\
Latar Belakang Pendidikan Komisaris & $-5,02$ &, 619 \\
\hline Sumber: Data primer diolah, 2020 & &
\end{tabular}

Berdasarkan Tabel 1 diketahui bahwa struktur modal mempunyai nilai t hitung sebesar $-1,951$ dengan tingkat signifikansi sebesar 0,059. Dari data tersebut dapat disimpulkan bahwa nilai $\mathrm{t}$ hitung $<\mathrm{t}$ tabel $(-1,951<2,0301)$ dan nilai signifikansi lebih dari $0,05(0,059>0,05)$, maka $\mathrm{H}_{0}$ diterima dan $\mathrm{H}_{1}$ ditolak, artinya struktur modal tidak berpengaruh terhadap kinerja perusahaan. Artinya semakin besar pendanaan modal perusahaan dari liabilitas atau hutang tidak berpengaruh terhadap kinerja perusahaan. Ukuran perusahaan memiliki nilai t hitung sebesar 2,105 dengan nilai signifikansi sebesar 0,43. Dari data tersebut dapat disimpulkan bahwa nilai $\mathrm{t}$ hitung $>\mathrm{t}$ tabel $(2,105>2,0301)$ dan nilai signifikansi lebih dari 0,05 (0,043>0,05), maka $\mathrm{H}_{0}$ ditolak dan $\mathrm{H}_{2}$ diterima, artinya ukuran perusahaan berpengaruh signifikan positif terhadap kinerja perusahaan. Artinya semakin besar ukuran perusahaan dengan proxy total penjualan maka akan semakin baik kinerja perusahaan. Sedangkan latar belakang pendidikan dewan komisaris memiliki nilai t hitung sebesar -5.02 dengan nilai signifikansi sebesar 0.619. Dari data tersebut dapat disimpulkan bahwa nilai $t$ hitung $<\mathrm{t}$ tabel $(-5.02<2.0301)$ dan nilai signifikansi lebih dari $0.05(0.619>0.05)$, maka $\mathrm{H}_{0}$ diterima dan $\mathrm{H}_{3}$ ditolak, artinya latar belakang pendidikan dewan komisaris tidak berpengaruh terhadap kinerja perusahaan. Artinya anggota dewan komisaris memiliki latar belakang pendidikan manajemen ataupun tidak memiliki latar belakang pendidikan manajemen tidak mempengaruhi kinerja perusahaan. 
Tabel 2. Hasil Model Regresi Berganda

\begin{tabular}{lrr}
\hline & \multicolumn{1}{c}{$\boldsymbol{B}$} & Std. Error \\
\hline (Constant) & $-1,500$ & 1,201 \\
Struktur Modal &,- 608 &, 312 \\
Ukuran Perusahaan &, 082 &, 039 \\
Latar Belakang Pendidikan Komisaris &,- 163 &, 325 \\
\hline Sumber: Data primer diolah, 2020 & &
\end{tabular}

Berdasarkan tabel 2, maka model persamaan regresi linear berganda yang terbentuk adalah sebagai berikut:

$\mathrm{Y}=-1,500-0,608 \mathrm{SM}+0,082 \mathrm{UP}-0,163 \mathrm{PK}+\mathrm{e}$

Keterangan:

$\mathrm{Y}=$ Kinerja Perusahaan

$\mathrm{SM}=$ Struktur Modal

UP = Ukuran Perusahaan

PK = Latar Belakang Pendidikan Dewan Komisaris

$\mathrm{e} \quad=$ Standard Error (Kesalahan Gangguan)

Berdasarkan persamaan regresi tersebut maka dapat dilakukan suatu analisa pengaruh masing-masing variabel independen yaitu struktur modal (X1), ukuran perusahaan (X2), dan latar belakang pendidikan dewan komisaris (X3) terhadap variabel dependen yaitu kinerja perusahaan (Y) sebagai berikut:

1. Nilai konstanta $(\alpha)$ atas hasil regresi pada penelitian ini sebesar -1,500 yang artinya, jika semua variabel bebas (struktur modal, ukuran perusahaan, dan latar belakang pendidikan dewan komisaris) bernilai 0, maka kinerja perusahaan bernilai -1,500. Konstanta negatif artinya terjadi penurunan kinerja perusahaan sebesar 1,500.

2. Struktur modal memiliki nilai koefisien regresi sebesar $-0,608$ artinya bahwa setiap terjadi kenaikan struktur modal sebesar 1 satuan, maka akan menurunkan nilai kinerja perusahaan sebesar 0,608 satuan.

3. Ukuran perusahaan memiliki nilai koefisien regresi sebesar 0,082 artinya bahwa setiap terjadi kenaikan ukuran perusahaan sebesar 1 satuan, maka akan menaikkan nilai kinerja perusahaan sebesar 0,082 satuan.

4. Latar belakang pendidikan dewan komisaris memiliki nilai koefisien regresi sebesar 0,163 artinya bahwa setiap terjadi kenaikan latar belakang pendidikan dewan komisaris sebesar 1 satuan, maka akan menurunkan nilai kinerja perusahaan sebesar 0,163 satuan.

\section{PEMBAHASAN}

Hasil pengujian menunjukkan bahwa struktur modal tidak berpengaruh terhadap kinerja perusahaan, artinya seberapapun besar pendanaan modal perusahaan dari liabilitas atau utang tidak berpengaruh terhadap kinerja perusahaan. Kayobi dan Anggreani (2015) menjelaskan bahwa besar kecilnya hutang yang dimiliki perusahaan tidak terlalu diperhatikan oleh investor, karena investor lebih melihat bagaimana pihak manajemen perusahaan menggunakan dana tersebut dengan efektif dan efisien untuk meningkatkan kinerja perusahaan. Hasil ini tidak konsisten dengan penelitian yang dilakukan oleh Dahar, et. al., (2019) yang menyatakan bahwa struktur modal yang diproksikan dengan DER (Debt to 
Equity Ratio) berpengaruh terhadap kinerja perusahaan. Namun penelitian ini konsisten dengan Kayobi dan Anggreani (2015) yang menyatakan bahwa struktur modal yang diproksikan dengan DER (Debt to Equity Ratio) tidak berpengaruh terhadap kinerja perusahaan.

Ukuran perusahaan berpengaruh signifikan positif terhadap kinerja perusahaan. Artinya semakin besar total penjualan sebuah perusahaan maka semakin baik kinerja perusahaan. Hal ini didukung oleh Kuncova et. al., (2016), dan Kartikasari \& Merianti (2016) yang mengindikasikan pengaruh signifikan positif. Kinerja perusahaan memiliki hubungan dengan tingkat penjualan. Perusahaan yang memiliki total nilai penjualan yang besar dianggap memiliki kemampuan dalam menghasilkan laba lebih besar daripada perusahaan yang memiliki total nilai penjualan yang lebih rendah. Adanya laba yang meningkat mengindikasikan bahwa kinerja perusahaan khususnya kinerja keuangan membaik (Kartikasari dan Merianti, 2016).

Hasil pengujian menunjukkan bahwa latar belakang pendidikan dewan komisaris tidak berpengaruh terhadap kinerja perusahaan. Hal ini didukung oleh penelitian Dewi, et. al., (2018), yang mengindikasikan bahwa tidak ada pengaruh antara latar belakang pendidikan dewan komisaris dengan kinerja keuangan. Penelitian ini kontra dengan penelitian yang dilakukan oleh Suhardjanto, et. al (2017) yang menyatakan bahwa latar belakang pendidikan dewan komisaris memiliki pengaruh positif pada kinerja perusahaan, hal ini dikarenakan seseorang dengan tingkat pendidikan yang lebih tinggi akan lebih rasional dalam mengolah informasi dan mengambil kebijakan, disamping mereka memahami tugas serta tanggung jawab mereka. Dalam pengambilan keputusan atas masalah yang terjadi di perusahaan mungkin tidak hanya terus menerus tentang tata kelola atau pun administrasi perusahaan, bisa saja tentang masalah teknis yang berhubungan dengan bidang usaha dari perusahaan itu sendiri, mengingat bidang usaha pada perusahaan sampel bermacam-macam mulai dari bidang farmasi, makanan dan minuman, rokok, dan lainnya maka anggota komisaris dengan latar belakang pendidikan diluar pendidikan manajemen, seperti engineering, dokter, atau hukum juga berkontribusi dalam kinerja perusahaan.

\section{SIMPULAN DAN SARAN}

Adapun penelitian ini dapat disimpulkan sebagai berikut Struktur Modal tidak berpengaruh terhadap Kinerja Perusahaan, Ukuran Perusahaan berpengaruh signifikan positif terhadap Kinerja Perusahaan, sedangkan Latar Belakang Pendididkan Dewan Komisaris tidak berpengaruh terhadap Kinerja Perusahaan. Saran dari peneliti untuk penelitian selanjutnya adalah agar dapat menggunakan sampel yang lebih luas, tidak terpaku pada perusahaan manufaktur sektor industri barang konsumsi dan periode penelitian lebih dari tiga tahun sehingga memiliki cakupan yang lebih luas. 


\section{DAFTAR PUSTAKA}

Ahmed, F., S. Talreja, dan M. Kashif. (2018). Effects of Corporate Governance and Capital Structure on Firm's Performance: Evidence from Major Sectors of Pakistan. Indonesian Capital Market Review, Vol. 10. Page 90-104.

Dahar, R., N. S. P. Yanti, dan F. Rahmi. (2019). Pengaruh Struktur Modal, Ukuran Perusahaan, dan Return On Equity Terhadap Nilai Perusahaan Property dan Real Estate yang Terdaftar di Bursa Efek Indonesia. Jurnal Ekonomi \& Bisnis Dharma Andalas, Vol. 21, No. 1.

Dewi, A. S., D. Sari, dan H. Abaharis. (2018). Pengaruh Karakteristik Dewan Komisaris Terhadap Kinerja Perusahaan Manufaktur Di Bursa Efek Indonesia.Jurnal Benefita, Vol. 3. No. 3.

Jensen, M., C., dan W. Meckling. (1976). Theory of the firm: Managerial behavior, agency cost and ownership structure. Journal of Finance Economic 3:305-360, di-download dari http://www.nhh.no/for/courses/spring/eco420/jensen-meckling-76.pdf

Kartika, Andi. (2016). Pengaruh Profitabilitas Struktur Aset, Pertumbuhan Penjualan Dan Ukuran Perusahaan Terhadap Struktur Modal Perusahaan Manufaktur di Bursa Efek Indonesia.INFOKAM, No. 1 Th. XII/Maret/2016.

Kartikasari, D. dan Merianti, M. (2016). The Effect of Leverage and Firm Size to Profitability of Public Manufacturing Companies in Indonesia. International Journal of Economics and Financial Issues, 6(2), 409-413.

Kayobi, I.GM.A dan D. Anggraeni. (2015). Pengaruh Debt To Equity Ratio, Debt To Total Asset, Deviden Tunai dan Ukuran Perusahaan Terhadap Nilai Perusahaan (Perusahaan Manufaktur Sektor Barang Konsumsi Yang Terdaftar Di Bursa Efek Indonesia Periode 2011-2014). Jakarta : Universitas Budi Luhur.

Kuncova, M., V. Hedija, dan R. Fiala. (2016). Firm Size as a Determinant of Firm Performance: The Case of Swine Raising. Agris on-line Papers in Economics and Informatics, Vol. 08, No. 3.

Scott, William R. (1997). Financial Accounting Theory. International Edition. New. Jersey : Prentice-Hall, Inc.

Smithers, A. dan Wright, S. (2008). Valuing Wall Street. Mc Graw Hill.

Suhardjanto, D., Alwiyah, Jatmiko, dan Nurudin, A. (2017). Ownership Structure And Financial Performance: An Empirical Study Of Listed Airlines Industry In Asia And Australia. Review of Integrative Business and Economics Research, Vol. 6, Supplementary Issue. ISSN: 2304-1013.

Puspitasari, B. dan U. Hartono. (2016). Pengaruh Ukuran Dewan Direksi, Ukuran Komite Audit dan Ukuran Perusahaan Terhadap Kinerja Perusahaan Sektor Pertambangan yang Terdaftar di BEI Tahun 2011-2014.Jurnal Ilmu Menejemen, Vol. 21 
Taouab, O. dan I. Zineb. (2019). Firm Performance: Definitions and Measurement Models. European Scientific Journal, Vol. 15, No. 1.

Widiastri, P., A. dan G. W. Yasa. (2018). Pengaruh Profitabilitas, Free Cash Flow, dan Ukuran Perusahaan pada Nilai Perusahaan. E-Jurnal Akuntansi Universitas Udayana, Vol. 23, No. 2.

Wijayati, F. L. (2015). Analisis Pengaruh Kepemilikan Manajerial, Kepemilikan Institusional, Ukuran Dewan Direksi, Dan Ukuran Dewan Komisaris Terhadap Biaya Keagenan. Jurnal EBBANK, Vol. 6, No. 2. 